\title{
Demonic Temporality in Marlowe's Doctor Faustus
}

\author{
KATHERINE WALKER
}

UNIVERSITY OF NEVADA, LAS VEGAS

Does the Devil feel the passage of time? How can human agents align their idiosyncratic experiences of change with otherworldly beings? Why, for example, does Faustus request only twenty-four years from the ageless Mephistopheles, when presumably one of magic's boons might be the extension of human life beyond a typical scope? ${ }^{1}$ As ludicrous as these questions might appear, for most Renaissance individuals the Devil was a continued, active presence, and these inquiries were integral to contemporary demonological discourse. Satan, like Scottish witches or malignant planets, could shape national historical narratives. ${ }^{2}$ His long duration on earth, demonologists claimed, allowed him to wield a vast corpus of knowledge, which he used to gull magicians and witches into believing that they too might gain epistemic and temporal omnipotence from a demonic contract. ${ }^{3}$ Not subject to the same vicissitudes of bodily decay,

\footnotetext{
${ }^{1}$ That "scope," however, was continually redefined in sixteenth- and seventeenth-century medical tracts. Longevity was a major preoccupation of the period, furnishing the metaphorical "ages" of humankind in poetic conceits. See Daniel Schäfer, Old Age and Disease in Early Modern Medicine, trans. Patrick Baker (New York: Pickering \& Chatto, 2016).

${ }^{2}$ On the period's vast literature in demonology, see esp. Stuart Clark, Thinking with Demons: The Idea of Witchcraft in Early Modern Europe (Oxford: Oxford University Press, 1999). For demonology and the Devil in early modern England, see Nathanael Johnstone, The Devil and Demonism in Early Modern England (Cambridge: Cambridge University Press, 2006); Charlotte-Rose Millar, Witchcraft, the Devil, and Emotions in Early Modern England (New York: Routledge, 2017); and Darren Oldridge, The Devil in Early Modern England (Stroud: Sutton, 2002). Works that treat the presence of the devil on the early modern stage include John Cox, The Devil and the Sacred in English Drama, 1350-1642 (Cambridge: Cambridge University Press, 2000); Jan Frans Van Dijkhuizen, Devil Theatre: Demonic Possession and Exorcism in English Renaissance Drama, 1558-1642 (Cambridge: Boydell \& Brewer, 2007); Mary Floyd-Wilson, Occult Knowledge, Science, and Gender on the Shakespearean Stage (Cambridge: Cambridge University Press, 2013); and Kristen Poole, Supernatural Environments in Shakespeare's England: Spaces of Demonism, Divinity, and Drama (Cambridge: Cambridge University Press, 2011). This essay in many ways serves as the counterpart to Poole's emphasis on the geometric supernaturalisms of the period, or the means through which demonic and otherworldly presences were understood through geometric frameworks. By approaching demonic beings through a temporal lens, I show how otherworldly beings served as useful hermeneutics for understanding the human condition of mortality on the early modern stage. Poole captures the capacious sense of how the Devil could make himself felt in early modern lives: "From thunderstorms to erotic dreams, from the workings of the cosmos to the musings of the soul, the devil was an immediate, active presence in people's lives. He was ubiquitous and unavoidable" (26).

${ }^{3}$ This was a typical claim, and warning, on the part of demonologists. Echoing a long tradition that hearkens back to Krammer's Hammer, for example, Nathanael Homes's 1650 demonology lists Satan's many areas of expertise: "[T]he Devil, being a spirit of exceeding knowledge (for hee lost onely his goodnesse) He understanding better then men the Prophesies of the Old Testament, the secrets of nature, what nature may be heightened unto in being, or
} 
demonic agents experienced time differently. The Devil could afford to work slowly, over generations, or rapidly; Iago, for example, picks up on this temporal freedom when he compares the alacrity of magical effects to his own, temporally constrained schemes: “Thou know'st we work by wit and not by witchcraft / And wit depends on dilatory time" (2.3.367-68). ${ }^{4}$ Witchcraft and the demonic agents associated with it, to follow Iago's thinking, can achieve an instant gratification of pleasures, a preternaturally compressed duration between desire and fulfillment. In the early modern period, there was a unique timescale for otherworldly figures and their subjects, which fell outside of the protracted lifespans delimited by human cognition, that “dilatory time" of which Iago complains. Demons, however, experienced a mode of living and working within multiple eras that challenged the early modern period's delineation of temporalities in strictly historical and eschatological frames.

I pose the above questions as potentially ridiculous to specifically modern readers, but there is also the sense in early modern drama that such questions are risible. While playing upon genuine belief in demonic influences, works such as Friar Bacon and Friar Bungay, The Devil's Charter, or The Devil Is an Ass also expose the hubris in the period's demonological traditions. ${ }^{5}$ Demonology shares with the period's other sciences an attempt to capture the capaciousness of all possible knowledge, and authors aimed to forecast precisely what might be expected of preternatural agents, not only how but when they might arise. While demonologists subjected the Devil's intervals of influence on earth to serious, extended, and entangled debate, the stage, I suggest, does something different with the temporal experiences of preternatural beings. Despite learned forays into the subject, the history of Satan and his agents, playwrights intimate, cannot be written. ${ }^{6}$ Or rather, such expositions represent only a glimpse at the many flights attributed to

operation, and the dependence of actions, both naturally and morally, oft times doth hitt right in Predictions." In Daemonologie, and Theologie The first, the Malady, Demonstrating the Diabolicall Arts, and Devillish Hearts of Men. The second, the Remedy: Demonstrating, God a Rich Supply of all Good (London, 1650), C3v.

${ }^{4}$ William Shakespeare, Othello, ed. E. A. J. Honigmann (London: Bloomsbury, 2014).

${ }^{5}$ Devils were a staple of early English drama. Mystery plays often featured demonic figures, such as the Vice but also Lucifer himself, and the early modern commercial theaters capitalized on the spectacular and affective force of presenting otherworldly beings to an audience who believed in the reality of these figures. Cox observes the sweeping influence of the Devil in English theater: "Aside from human beings, nothing was staged more continuously in early English drama than the devil and his minions. For about 300 years - from the late fourteenth century to the late seventeenth - playwrights regularly put devils on stage in every kind of English play for every kind of audience, whether aristocratic, popular, or commercial" (5).

${ }^{6}$ Though later authors, including John Milton, Daniel Defoe, and C. S. Lewis would think differently. Defoe's The Political History of the Devil (London, 1726), however, has its own historiographical limitations, as Defoe admits in discussing Satan's origin: "To come to a regular enquiry into Satan's affairs, 'tis needful we should go back to his 
the Devil. In early modern drama, playwrights stage an uneasy, yet productive, shift away from demonological discourse towards more playful, literary considerations of what demonic time might mean for understanding the limitations of human duration on earth. ${ }^{7}$ Stage devils are fickle, sometimes arriving suddenly and at other times suspending their appearance onto the playing boards, savoring the theatricality of seducing figures like Faustus to damnation. Whether characterized by rapidity or procrastination, within this wide range of performances of demonic time the stage provided a fresh interpretation of the temporal constraints of all of God's creatures, good and evil alike.

In this essay, I discuss how Marlowe's Doctor Faustus engages with the concept of what I term demonic temporality. As we shall see, demonic temporality is unique precisely because it cannot be explicated entirely, and the imaginative potential of preternatural experiences of time functions as a type of negative blueprint - demonic temporality has the ability to puncture any delineated model of Christian epochs demarcated into the "ages" of theological time. ${ }^{8}$ Rather than work against this ontological constraint, the stage uses preternatural temporality to create a space for considering how human agents can never achieve that immortality promised, in Faustus's words, to the "studious artisan" (1.57) of the dark arts. ${ }^{9}$ Faustus seeks to gain knowledge of the Devil's temporal singularity compared to other beings, and the play dwells on the hubris of attempting to align demonic temporality with human expectations. In Doctor Faustus the conflicts between preternatural and natural timescales establish an imaginative entryway into demonology that subjects to mockery the period's ambitions in charting multiple

\footnotetext{
original, as far as history and the opinion of the learned World give us leave" (31). This "leave" is tethered to divine writings and human scholars, and Defoe recognizes that his history of Satan can only approximate full understanding of demonic temporality. Much more recently, Philip C. Almond has written a biography of Satan, The Devil, A New Biography (Ithaca, NY: Cornell University Press, 2014).

${ }^{7}$ To be clear, these plays traffic in the real fear that the Devil could elicit for their audiences. See Andrew Sofer, "How to Do Things with Demons: Conjuring Performatives in Doctor Faustus," Theatre Journal 61, no. 1 (2009): 1-22 for a discussion of the performative power of incantations and conjurations on the early modern stage. But, as I argue, we can both take seriously the period's beliefs in demonic powers while also considering how there was room for jest; playwrights depict trickery, improvisation, and playfulness among preternatural beings and their human interlocutors.

${ }^{8}$ Sir Thomas Browne's outline of Satan's methods for deception neatly articulates the limitations to this practice: "To attempt a particular of all his wiles, is too bold an Arithmetick for man," and instead Browne paints in broad strokes the Devil's devices. See Pseudodoxia Epidemica in Sir Thomas Browne: The Major Works, ed. C. A. Patrides (Harmondsworth: Penguin, 1977), 193.

${ }^{9}$ All in-text citations refer to Doctor Faustus in Christopher Marlowe: The Complete Plays, ed. Frank Romany and Robert Lindsey (London: Penguin, 2003). This edition is based on the A-text. For discussion on the differences between the two texts, see the Introduction to Doctor Faustus: A-and B-Texts $(1604,1616)$, ed. David Bevington and Eric Rasmussen (Manchester: Manchester University Press, 1993).
} 
histories. My discussion points to how this derision nonetheless fails to dispel entirely the appeal of grasping the specific qualities of demonic experiences of time; although in this case at crosspurposes, both demonology and demonological dramas have much to teach us about how Satan and his troops might help conceptualize the period's tricky understanding of humans embedded within multiple, but nonetheless circumscribed, historical frameworks. Doctor Faustus allows us not only to consider demonic temporality, but also to understand how the period's investment in dissecting experiences of time utilized a preternatural agent as a comparative hermeneutic.

Temporal consciousness in the period enfolded more discourses than the familiar arts of mechanics, anatomy, or astronomy, and instead embraced the ontological insights within demonological tradition. ${ }^{10}$ The Devil is both amid and beyond narratives, and thus his experiences of time often baffle authors, who nonetheless attempt to explicate comprehensively demonic temporality's many nuances by comparing it to a specifically human understanding and experience of the progression of time. "Sathan hee is busie," wrote Christopher Sutton, "because his time is short, and therefore his wrath is the fiercer. But wee remembring the continuance of time, should vse all diligence, and therefore our care should be the greater to preuent the subtile Serpent." "Sutton urges his readers to balance diverse registers of time in his warning: while Satan is "busie" in the sense that he might feel a sense of urgency to convert dying individuals to his kingdom, Sutton's readers are reminded of "the continuance of time" beyond one's lifespan. My analysis, then, is not to provide merely an impressionistic account of something arcane and embedded in the recesses of early modern culture. Instead, one of my aims is to describe a particular lens that shaped how early modern authors and audiences perceived the cadences of natural rhythms in contradistinction to preternatural ones, particularly before death. Demonic temporalities were a way for individuals to conceptualize their own timescapes, to consider the adage tempus fugit (time flies) through complex models that reached beyond simply the idea that time is marked by individual and national historical events.

\footnotetext{
${ }^{10}$ Here I am referencing recent studies on specific aspects of scientific or mechanical innovation in timekeeping in the period, including Paul Glennie and Nigel Thrift, Shaping the Day: A History of Timekeeping in England and Wales, 1300-1800 (Oxford: Oxford University Press, 2009) and David Lande, Revolution in Time: Clocks and the Making of the Modern World (Cambridge, MA: Harvard University Press, 2000). Amy Boesky discusses the gendered dynamics to using timepieces in the period, arguing for "time as a crucial marker in talking about gender" in "Giving Time to Women: The Eternising Project in Early Modern England," in This Double Voice: Gendered Writing in Early Modern England, ed. Danielle Clarke and Elizabeth Clarke (Basingstoke: Macmillan, 2000), 132.

${ }^{11}$ Christopher Sutton, Disce mori. Learne to die. A religious discourse, moouing euery Christian man to enter into a serious remerbrance of his ende (London, 1600), 154.
} 
While this essay references the vast demonological literature of the period, I also turn more specifically to a different genre that took up preternatural temporality intimately. The ars moriendi, or the art of dying tradition, like drama, features extended debates between demons and the human who is soon to pass into another timeline, and the genre considered these last moments vastly consequential for whether one was saved or damned. ${ }^{12}$ The moriens, or dying individual, was thought to be confronted directly by Satan in this final battle over the soul, and the anxieties this departure provoked occasioned the genre's repeated refrains on the need to prepare for death. As Erasmus explained in one of the earlier texts of the ars moriendi, "We be wayfarynge men in this worlde, not inhabytantes, we be as straungers in Innes (or to speke it better) in bouthes or tentes, we lyue not in our countrey. This holle lyfe is nothinge elles but a rennynge to deathe, and that very shorte, but death is the gate of euerlastynge lyfe." ${ }^{13}$ Love for worldly goods and relationships, however, made this departure particularly difficult, and authors in the ars moriendi tradition sketch out the ways a dying individual could overcome this delimited understanding of one's narrative and achieve eventual triumph over Satan. Demons, in these texts, exhibit a sense of urgency, of seemingly unaccountable constriction that belies Iago's belief that preternature or magic need not consider temporal ends. As I show, Doctor Faustus features an aborted version of the ars moriendi, a scene which undermines the genre's theorization of Satan's timelines. In attending to how Faustus negotiates an understanding of demonic temporality, we witness how the stage toys with the ars moriendi tradition and the notion that, as human agents, we can interpret adequately how Satan's own timelines intersect but then overreach our own.

Instead of treating Satan, Mephistopheles, or other demonic familiars as characters specific to individual plays, I trace the representational dynamics of staging an out-of-time being interacting with human figures firmly embedded in multiple temporalities. These timescapes on the stage include iterative performances, the fictional scope of the narrative, recycled stage props, heritages of literary genres and conventions, and the early modern period as an historical

\footnotetext{
${ }^{12}$ Oddly, the genre remained relatively unchanged in its emphasis on the final moments preceding death. According to Richard Wunderli and Gerald Broce, "The Final Moment obviously was not the only attitude concerning death in the early modern period, but it seems to have been an important popular belief, one that ran counter to all theologies of death." See "The Final Moment before Death in Early Modern England," The Sixteenth Century Journal 20, no. 2 (Summer 1989): 261.

${ }^{13}$ Desiderius Erasmus, Preparation to deathe (London, 1538), A4v.
} 
epoch understood by contemporaries as moving ever closer to the end of time itself. ${ }^{14}$ Literature scholars have recently explored the unique temporal perspectives of the period, or how the early moderns themselves located their bodies and souls within linear, eschatological, and both synchronous and diachronous timelines. ${ }^{15}$ For David Scott Kastan, dramatic genre influences audiences' perception of time, and he uncovers the "ways in which dramatic structures are intimately connected with differing conceptions of the human experience in and of time" in Shakespeare's works. ${ }^{16}$ Doctor Faustus follows this dramatic innovation, and in Kastan's reading we have progressed from "[ $\mathrm{t}]$ he merciful, elastic time of Everyman" to "the unyielding, unforgiving time of Dr Faustus, in which the damnation of the Renaissance scholar is accomplished and assumed even by the Good Angel before the clock strikes twelve."17 Doctor Faustus is relentlessly moving towards that final moment before Faustus's damnation, and yet the play also slows down at certain moments, dwelling on the paucity of intellectual gains Faustus acquires from his fated contract.

Embroidering Faustus's imperfect grasp of the temporal stakes in his bargains with the Devil, the period's vast corpus of demonological and religious literature considered how Satan operates within and yet beyond time. Satan's story, at least in its plot points, is deceptively (and thus fittingly) straightforward. Identified by patristic authors with the talking serpent in the Garden of Eden, he appears in his fallen angelic state in the Book of Job, urging God to test Job's faith once his worldly goods and health are taken away from the righteous man, a loss

\footnotetext{
${ }^{14}$ Resonating throughout my readings of Doctor Faustus is the period's unique relationship to apocalypticism. Adrian Streete maps out the common eschatological narrative in post-Reformation England: "In Protestant interpretative culture, the eventual defeat of the Roman Catholic Church is taken as a necessary temporal prelude to the end of the world. Following the defeat of the antichrist, the true Church will be revealed, Christ will return to judge all, the dammed will be cast into a lake of fire, and the New Jerusalem of the elect will be established." Apocalypse and Anti-Catholicism in Seventeenth-Century Drama (Cambridge: Cambridge University Press, 2017), 8.

${ }^{15}$ A growing number of edited collections and monographs devoted to temporality in early modern England demonstrate the diversity of timescapes operating in fictional and historical narratives of the period. For an overview of the field, see Sarah Lewis, "Shakespeare, Time, Theory," Literature Compass 11, no. 4 (2014): 246-57. Recent works focusing on literature and time include J. K. Barrett, Untold Futures: Time and Literary Culture in Renaissance England (Ithaca, NY: Cornell University Press, 2016); Jonathan Gil Harris, Untimely Matter in the Time of Shakespeare (Philadelphia: University of Pennsylvania Press, 2009); Lauren Shohet, ed., Temporality, Genre and Experience in the Age of Shakespeare: Forms of Time (London: Bloomsbury, 2018); Matthew Wagner, Shakespeare, Theatre, and Time (London: Routledge, 2012); and David Houston Wood, Time, Narrative and Emotion in Early Modern England (Farnham: Ashgate, 2009).

${ }^{16}$ David Scott Kastan, Shakespeare and the Shapes of Time (London: Palgrave Macmillan, 1982), 7. For another influential account of time and performance in the period, see Rebecca Bushnell, Tragic Time in Drama, Film, and Videogames: The Future in the Instant (London: Palgrave Macmillan, 2016).

${ }^{17}$ Kastan, 6.
} 
reenacted iteratively in the early modern period when the moriens was urged to say farewell to everything he or she had ever owned. ${ }^{18}$ In Job, Satan arrives among a troop of angels: "Now on a day when the children of God came and stode before the Lord, Satan came also among them" (1:6 and again at 2:1). The gloss avers that the passage is written in familiar, materialized analogies to earthly ceremonies because "our infirmitie ca[n] not comprehend God in his maiestie, he is [therefore] set for the[e] vnto vs as a King, that our capacitie may be able to understand that, [which] is spoke[n] of him" (1:6 note 1). ${ }^{19}$ The annotator applies the same reasoning to Satan's scope of power and the scene that unfolds. In repeated moments of arriving before the throne of heaven, Satan tells God that he has been roaming capaciously; he arrives "[f]rom co[m]pasing the earth to and fro, and from walking in it" (1:7 and 2:2). Again, the gloss intervenes for the reader, clarifying that "[h]erein is described the nature of Satan, which is euer ranging for his pray [sic]" (1:7 note o). The brief appearances of Satan in Job appear to follow a cyclical pattern, in which Satan returns to God on separate days, after presumably some time has passed for Job to experience and contemplate his afflictions. The Book of Job establishes what would become a common motif in Satan's story: his sense of restlessness, of hurry to gather as many people into his diabolic fold as time permits. What is striking in these passages, however, is how Satan's actions mirror the temporal scheme of the narrative, despite the gloss that urges us to conceive of the story as only an approximation of divine bodies and time. The Devil's presence in Job is insistently temporal, mapped onto Job's own trajectory in a distorted sequential parallel of instigator and victim. The editor of the Geneva Bible is often insistently literal, and here such a reading, of tracing when and where Satan's body moves, structures Job's experiences of earthly, emphatically time-bound afflictions.

If Satan in Job appears somewhat abruptly before the throne of God and participates in Job's timeline as director and then spectator, he is elsewhere in Biblical tradition decidedly integral to and yet outside of the narrative, weaving throughout both Old and New Testaments and arriving quickly in moments of temptation or despair. ${ }^{20}$ In the New Testament Satan is consolidated among various demonic beings into the principal opponent of God, and

\footnotetext{
${ }^{18}$ On the influence of the Book of Job in the early modern period, see Victoria Brownlee, Biblical Readings and Literary Writings in Early Modern England, 1558-1625 (Oxford: Oxford University Press, 2018).

${ }^{19}$ The Geneva Bible, a Facsimile of the 1560 Edition, intr. Lloyd E. Berry (Geneva, 1560; Madison: University of Winsconsin Press, 1969), 222.

${ }^{20}$ On Satan in the New Testament, see Jeffrey Burton Russell, The Devil: Perceptions of Evil from Antiquity to Primitive Christianity (Ithaca, NY: Cornell University Press, 1977).
} 
demonologists of the medieval and early modern periods based their understanding of the Devil's powers on what he could do while attempting to lure Christ to forsake his Father (Matthew 4:1-11). ${ }^{21}$ But Satan's most explicit description, at least for later authors, is ironically at the end of the Biblical text. Reading Satan as the dragon of Revelation, early modern demonologists and clerics turned to the Devil's futurity as a call for their readers to heed their warnings. In Revelations, if we read Satan as the dragon, he has a distinct history and clear destiny:

And there was a battel in heauen. Michael \& his Angels foght against the dragon, and the dragon foght $\&$ his Angels. But they preuailed not, neither was their place founde anie more in heauen. And the great dragon, that olde serpent, called the deuil and Satan, was cast out, which deceiueth all the worlde: he we eue[n] cast into the earth, \& his Angels were cast out with him. (12:7-9).

Predating the Creation, Satan is coeval with angelic beings but not with God, who is outside of time. But the Devil too is beyond human experiences, at least when it comes to tracing his existence within various timescapes. Forcibly ejected from heaven, Satan is condemned to roam the earth, and thus to follow the seasonality of the material realm. In a sense, the Bible's description of Satan moves from considering a being once outside of time, then firmly embedded within it, and yet, ultimately, destined to someday be punished outside of any temporal constraints once again upon and following the Final Judgement.

Revelations also proffers explicit commentary on Satan's time on earth: “Therefore rejoice, ye heavens, and ye that dwell in them. Woe to the inhabiters of the earth and of the sea! for the devil is come down unto you, having great wrath, because he knoweth that he hath but a short time" (12:12). But Satan has been active since or before the beginning of human history, and therefore his "short time" is incalculably vast compared to that of his human expositors. In demonological tracts from the sixteenth and seventeenth centuries, such a delimitation of time to work his harms occasions a sense of urgency on the part of the devil. As Heinrich Bullinger

\footnotetext{
${ }^{21}$ Nonetheless, despite his powers of flight, ability to read human thoughts, and to cause disease, the Devil could not defy natural laws, or produce true miracles. In King James's Daemonologie, the interlocutor Epistemon asserts this knowledge in a temporal frame: "Was it not euill inough to deceiue simple ignorantes, in making them to take him for an Angell of light, and so to account of Gods enemie, as of their particular friend: where by the contrarie, all we that are Christians, ought assuredly to know that since the comming of Christ in the flesh, and establishing of his Church by the Apostles, all miracles, visions, prophecies, \& appearances of Angels or good spirites are ceased. Which serued onely for the first sowing of faith, \& planting of the Church. Where now the Church being established, and the white Horse whereof I spake before, hauing made his conquest, the Lawe and Prophets are thought sufficient to serue vs, or make vs inexcusable" (65-66), in Daemonologie in Forme of a Dialogue (Edinburgh, 1587).
} 
explains, "knowing that the last judgement is at hande, wherein he must be throwne headlong into hell," Satan works to use the dregs of the hourglass "to requite and recompence the shortnes of time with the crueltie of his wrath and develish furie." ${ }^{22}$ With such a keen sense of his own temporal limitations, the Devil and his agents are operating on a more expansive understanding of "short time," albeit one that is laughably protracted when placed against Faustus' twenty-four years or even Peter Fabell's bargaining for a mere seven years' delay until his demonic familiar Coreb carries him off to another temporal realm in the comedy The Merry Devil of Edmonton. Tricked into granting the magician Fabell several more years, the demon warns, "No time on earth, like Phaethonic flames, / Can have perpetual being" (1.79-80). ${ }^{23}$ Coreb aligns the magician with time, warning of the limitations that preternatural interactions can have-if markers of temporality will be destroyed upon the Last Judgement, no magical chairs or clever bargaining can prevent the fulfillment of divinely ordained ends.

As my brief reading of Satan in Biblical narrative evinces, Satan's story is anything but simple, and both early modern and present-day authors find plenty to extrapolate from these brief snapshots of a demonic, otherworldly being. Satan's many guises in the Bible and throughout early Christian history resulted in fault-lines in theorizations about the Devil's powers and his ability to enter into human timelines either bodily or through spiritual suggestion. Johann Weyer, for example, sums up the Devil's abilities and characteristics in a list that borders on the dizzying:

Therefore, these spirits which were previously divine, celestial, pure, bright, and conscious of no evil, which observed the will of God alone and were destined to be sent forth in service to those who were to be the heirs of salvation, have not lost their angelic essence entirely. But deprived as they are of original justice and the light of grace, they have hopelessly stained and blackened that essence so that they are now called, and in fact are, creatures of the lower atmosphere, creatures of this world, full of shadow and darkness - in short, unclean and evil. ${ }^{24}$

Compounding the issue was that debate over Revelation's thousand years in which the Antichrist is bound in hell led Protestant demonologists to speculate that from the harrowing of hell until the ascendancy of the Papacy, Satan was absent from history, and his reappearance in Catholic

\footnotetext{
${ }^{22}$ Heinrich Bullinger, A hundred sermons vpo[n] the Apocalips of Iesu Christe reueiled in dede by thangell of the Lorde (London, 1561), 363.

${ }^{23}$ Anonymous, The Merry Devil of Edmonton, ed. Nicola Bennett (London: Routledge, 2000).

${ }^{24}$ Johann Weyer, De praestigiis daemonum, in Witches, Devils, and Doctors in the Renaissance, ed. George Mora and translated by John Shea (Binghamton NY: Medieval and Renaissance Texts and Studies, 1991): 5.
} 
institutions, as the argument went, suggested that Satan had learned during his imprisonment to work with contemporary religion rather than against it. As the editor of William Perkins's $A$ Discourse of the Damned Art of Witchcraft Thomas Pickering suggests, "Christ the true angel of the Couenant, locked and bound vp Satan for a 1000. yeares after his ascension, that he might not be so generally powerfull in seducing the Gentiles, as he had beene before his incarnation...toward the expiration of those yeares...corruption began to creepe into the Papacie." 25 There was something reassuring in locating the one thousand years of Satan's captivity, even if that meant that the Devil was now let loose upon the earth. Wielding temporal authority, demonological authors could then more precisely situate religious change in eschatological frameworks.

In a range of beliefs about the time of Lucifer's ascendancy and potency upon earth, however, most early modern theologians and authors maintained that Satan intervenes deliberately into human affairs. And to do so effectively, authors implied, Satan has to cloak himself, or become embedded within, humanity's experiences of time. Turning to the ars moriendi tradition now, we can see vividly the ways in which authors figured a time-bound, indeed "busy" demonic being, constrained not by his own timeline but rather by that of a different creature altogether: the moriens. Nowhere is the sense of the Devil's pressing attempts to win individuals to damnation more vivid than in ars moriendi texts. ${ }^{26}$ In Thomas Becon's The Sicke Mans Salue, the moriens's friend Philemon delineates Satan's methods precisely, focusing on the performance of both Satan and the moriens:

The manner of Satan, which is the common aduersary of all men, is, whe[n] any ma[n] is greuously sicke $\&$ like to die, straightways to com vpon him at the beginning very fearcely, \& to shew him selfe terrible vnto him, \& to cast before his eies such a mist: that except he taketh hede, he shall see nothing but the fearce wrath, \& terrible iudgement of God against sinners, again, synne, desperatio[n], death and hel, and whatsoeuer maketh vnto the utter confusion of the sickmans conscie[n]ce. ${ }^{27}$

Philemon is confident in his explication, patiently mapping out the precise "manner" of Satan for his dying companion. Other ars moriendi texts, in their visual and textual content, are less reassured in tone regarding how and when the Devil will appear at one's deathbed. But each text

\footnotetext{
${ }^{25}$ Thomas Pickering, preface to William Perkins, A Discourse of the Damned Art of Witchcraft (London, 1610), n.p.

${ }^{26}$ For a persuasive reading of the tradition on the early modern stage, see Maggie Vinter, Last Acts: The Art of Dying on the Early Modern Stage (New York: Fordham University Press, 2019). Vinter is also invested in Doctor Faustus's negotiation of multiple timescapes, though Vinter focuses on the "parodic bad death" (32) in the play.

27 Thomas Becon, The sicke mans salue (London, 1568), 349-50.
} 
in the genre maintains the dangers of this particular moment for the moriens's soul and all figure the time before death as a performance; there was such a thing as a good death, one in which the moriens follows a script and anticipates the arrival of demons to tempt him or her.

As we will see, Doctor Faustus concludes with a death scene, a bad death, and the drama considers the strategies of demonic playing with time. Reading demonic temporality in ars moriendi tracts, I argue, illuminates the continuities with the art of dying that Doctor Faustus adopts while also highlighting where dramatic texts might diverge in presenting ludic interchanges among demons and tricksters. As early modern divines and other authors declared, no time was so crucial to understanding one's own temporal limitations as the hours or even minutes leading up to one's death. The ars moriendi tradition is a useful frame for thinking about demonic temporality in a play that is bracketed by such poignant debates about the possibility of an eternity in hell and Satan's contractual bargaining to make such a space more populated with his followers. "For this is of mans lyfe the last part (as it were) of the playe," Erasmus declares to his patron, "wherof hangeth eyther euerlastynge blysse of man, or euerlastynge damnation." 28 Figuring human existence as a stage performance or marathon, Erasmus's ars moriendi text locates Satan as not only a spectator but an active participant in this event, running towards his doom alongside those he converts to his kingdom.

Ars moriendi texts began to proliferate in the early fifteenth century, and the Reformation and the dissolution of purgatory in England's institutionalized theologies did not, ironically, do away with the import afforded to this last battle over the moriens's soul. ${ }^{29}$ The art of dying well specified that, unless an accidental death occurred, the moriens should prepare diligently for a final confrontation with Lucifer; many of the texts in the genre provide template dialogues, performing the ideal ways to counteract Satan's last-ditch attempt to gain a new inhabitant for his realm. Authors in the craft of dying tradition emphasize how the Devil distorts human understanding of their own timescales. As Sutton reminds his readers, Satan works "by stealing from their hartes this remembrance of their ende." ${ }^{30}$ Indeed, Satan's greatest ploy is to focus on the moriens's earthly temporality, and he often intimates that there is nothing beyond the

\footnotetext{
${ }^{28}$ Erasmus, Preparation to deathe, A2r.

${ }^{29}$ These texts followed earlier versions, particularly the Speculum, artis bene moriendi dating from 1414-18. On the ars moriendi's history, see Nancy Lee Beaty, The Craft of Dying: A Study in the Literary Tradition of the ars moriendi in England (New Haven: Yale University Press, 1970).

${ }^{30}$ Sutton, Disce mori, 60.
} 
immediate experiences of time that the dying subject has known. Again, Sutton articulates this notion, this time with a metaphor of a usurer lending money to a gambler: "It is the generall practise of Sathan to promise carelesse sinners time enough: as racking, vsurers are wont to giue day to yong heires, from time to time, vntil at last they wind their inheritance from them. Wee know not how dangerous it is to deferre all vnto the last cast." ${ }^{\text {"1 }}$

In Philip Stubbes's account of his wife Katherine's death, in line with the typical moriens's narrative, she speaks to a Satan that is only visible to herself. Katherine puts to use the temporal discourses of contemporary demonology, inscribing herself in multiple eschatological timeframes that do not, she insists, include the Devil:

How now Satan? What makest thou here? Are thou come to tempt the Lords seruante? I tell thee, thou hell hound, thou hast no part nor portion in me: nor by the grace of God neuer shalt have. I was, now am, and shall be the Lords for euer. Yea Satan, I was chosen $\&$ elected in Christ to euerlasting saluation before the foundations of the world were laid: and therefore thou must get thee packing, thou damned Dog, and goe shake thine eares, for in me thou hast nought. ${ }^{32}$

Katherine's rebuttal of Satan, in its highly Calvinist inflections, imparts to Satan her insistence that she too is outside of time, but hers is a divinely prescribed timeframe, where her existence and salvation were predetermined at the moment of Creation. To Katherine, Satan never has had nor ever will possess her soul, and her argument relies on a keen, indeed rapid, temporal progression: "I was, now am, and shall be the Lords for euer" she contends; even in the poignant moment of a present temptation and confrontation, Katherine's language moves quickly beyond the moment of death to a futurity in which the bestial tempter has no part.

If Katherine's exchange with Satan excludes him from an imagined salvific future, other authors in the tradition associated Satan closely with the past and present- the Devil is of a declining earthly temporality, one that is quickly reaching its end. And to chart this progression was to provide some means for counteracting the Devil's influence. As Mephistopheles attempts to convey to Faustus, Lucifer is an aged being, and Mephistopheles is thus coeval with his master, one of the "[u]nhappy spirits that fell with Lucifer, / Conspired against our God with Lucifer, / And are for ever damned with Lucifer" (4.72-74). But Faustus cannot countenance or grasp the extent of "for ever damned," and he seems to revel in a fantasy

\footnotetext{
${ }^{31}$ Sutton, 302 .

${ }^{32}$ Philip Stubbes, A Christal Glas for Christian Women (London, 1591), C2v.
} 
of iteration, of continued opportunities to replay the script: "Had I as many souls as there be stars, / I'd give them all for Mephistopheles" (4.104-5). Mephistopheles encourages this delusion, even as his language exhibits some slippage in tempting Faustus to this materialized, earthly understanding of time. He promises, for example, to present Faustus with any paramour he desires, "[b]e she as chaste as was Penelope, / As wise as Saba, or as beautiful / As was bright Lucifer before his fall" (5.157-59). In this fantasy of unlimited desires and iterative sexualized encounters, Mephistopheles reverts to emplacing Lucifer in a temporal frame, one that should remind Faustus that the Devil was once "most dearly loved of God" (3.67) but has now been transmuted into a different, much less settled narrative.

Using time as a manipulative tool, preternatural figures are, in a sense, deriding a human construct of temporality that ascribes particular importance to astrological or diurnal markers of seasonality, or even the idea that performance depends on evoking specific times. Instead, evil is always at hand. More directly, in Reginald Scot's disbelief over whether witches truly harness the power of demons, at the same time he espouses his belief that the Devil can work at any time: "IF Witches could do any such miraculous things, as these and other which are imputed to them, they might do them again and again, at any time or place, or at any mans desire: for the devil is as strong at one time as at another, as busie by day as by night, and ready enough to do all mischief, and careth not whom he abuseth." 33 Faustus, like the witches Scot refers to, often specifies that he will conjure and study the black arts during the deep of night. As he proclaims with rhetorical flourish, "Now that the gloomy shadow of the earth, / Longing to view Orion's drizzling look, / Leaps from th'Antarctic world unto the sky / And dims the welkin with her pitchy breath," or now, more prosaically, that the sun has set, he will "begin thine incantations" $(3.1-4,5)$. Scot would likely laugh at Faustus's precision in specifying such moments for his conjuration, for Faustus not only believes in the virtue of night, but rather is "well grounded in astrology" (1.140), and thus attentive to the movement of the heavens upon earthly bodies. Faustus has prepared to raise Mephistopheles using "[ $\mathrm{t}]$ he breviated names of holy saints, / Figures of every adjunct to the heavens," alongside an ephemeris or astrological chart, those "characters of signs and erring stars, / By which the spirits are enforced to rise" $(3.10-11,12-$ 13). By paying close attention to astral time, Faustus believes that he can control demonic spirits, using in this case the idea of time itself as a type of ingredient or constitutive element in his

\footnotetext{
${ }^{33}$ Reginald Scot, The Discovery of Witchcraft (London, 1584), 7.
} 
conjuration. Of course, this formulation is all undercut by Mephistopheles' admission that he arrived "of mine own accord" (3.45).

Beyond his own temporal constraints, Satan tricks magicians into believing, as James I puts it, "[t]here ar likewise certaine seasons, dayes and houres" which the conjuror should observe to raise spirits. ${ }^{34}$ This trick on Satan's part is most forcibly apparent when the clowns Robin and Rafe raise Mephistopheles on a whim, thus turning Faustus's precision in conjuration to mockery. ${ }^{35}$ If clowns might call forth the devil at any time, then Faustus's emphasis on turning to conjuration in the deep recesses of night is all the more laughable, a ceremonialism that Marlowe's play quickly deflates and debases. Hamlet may express anticipation because "' $[\mathrm{t}]$ is now the very witching time of night," (3.2.378), but for sceptics like Scot every hour was susceptible to demonic interludes. ${ }^{36}$ Demons need no unique seasons to arrive from hell-everpresent at the ear of the sinner, they only seemingly require specific times to appear within the conjuror's circle. And they are always at hand by a deathbed, in which case any moment in which death approaches is also a time of particular demonic resonance. Ultimately, despite attempts to locate demonic temporality among a spectrum, a plot line with a clear logic, Doctor Faustus empties out all the ontological force of such demonological claims of temporal force, showing that time is not simply linear, but cosmic and yet undifferentiated, for both conjuror and demonic familiar.

Scot expands on the ways that humans believe that Satan is lured by the specificity of times or seasons in their magical practice, and he works to undo the contemporary belief that demonic activity is more potent at certain astrological and seasonal alignments than at others. Disparaging Jean Bodin's conclusions on demonic temporality, Scot reads his text and the Bible carefully for contradictions:

I find it not in the Bible, but in Bodin, that there are Day-Devils and Night-Devils. The same fellow saith, That Deber is the name of that Devil which hurteth by night; and Cheleb is he that hurteth by day howbeit, he confesseth, that Satan can hurt both by day and night; although it be certain (as he saith) that he can do more harm by night than by day; producing for example, how in a night he slew the first born of Egypt. And yet it

\footnotetext{
34 James VI \& I, Daemonologie, D1r.

${ }^{35}$ See my discussion of this moment below. It should be pointed out that this scene, and thus the inconsistency, is due to a different author of the scene. See Bevington and Rasmussen's introduction in Doctor Faustus: A- and BTexts (1604, 1616), p. 71-77, for discussion on Marlowe's possible collaborators.

36 William Shakespeare, Hamlet, ed. Ann Thompson and Neil Taylor (London: Bloomsbury, 2014).
} 
appeareth plainly in the Text, that the Lord himself did it. Whereby it seemeth, that Bodin puteth no difference between God and the Devil. ${ }^{37}$

Scot often returns to the blasphemy implied in witchmongers' beliefs regarding demonic ontological and epistemic powers. The impulse to catalogue devils by temporal registers, Scot avers, reaches a point of ridiculous pedantry, one that at once gives the Devil more power at certain times than God and also, paradoxically, delimits his powers during the day. Scot's outcry against misreading the Bible for one's own ideological position finds its parallel in Marlowe's play, when Faustus famously reads the New Testament selectively, refusing to read beyond the verses in I John 1:18, "Si peccasse negamus, fallimur / Et nulla est in nobis veritas [If we say that we have no sin, / We deceive ourselves, and there's no truth in us]" (1.42-45). Faustus does not read further into the Biblical text, which would promise salvation if one repents, and Faustus's selective reading narrows in on the harrowing temporality implied in the lines he does read:

Why then belike we must sin, And so consequently die.

Ay, we must die an everlasting death.

What doctrine call you this? Che serà, serà,

What will be, shall be? Divinity, adieu! (1.46-50).

Flippant regarding the "everlasting death" implied in his partial reading of the New Testament, Faustus is under the delusion that he himself controls time, that his conjurations enforce a "pliant" (3.30) Mephistopheles to appear before him.

At once fettered to natural laws and seasons and yet afforded so much control over human lives, Satan's experiences of time would seem to be a paradox. As I have been suggesting, the art of dying and demonological tracts from the period both conceive of an iterative performance upon the death of each dying human, and Satan's own sense of urgency can only be explained by considering the "short span" of human mortality. But the stage both condenses and protracts demonic temporality, playing with the idea that otherworldly beings escape any explanatory and thus temporal framework we might place them in. When Faustus first interacts with Mephistopheles, the magus questions him on the location of hell. But the spatial dimensions to Mephistopheles's answer are also temporal, something that Faustus of course only realizes too late. Mephistopheles tells Faustus:

\footnotetext{
${ }^{37}$ Scot, “A Discourse Concerning Devils and Spirits," in Discovery, 16.
} 
Why, this is hell, nor am I out of it.

Think'st thou that I, who saw the face of God

And tasted the eternal joys of heaven,

Am not tormented with ten thousand hells

In being deprived of everlasting bliss? (4.78-82).

The "ten thousand hells" are not specific locations, but rather are experiential, occurring rather than situated both physically and temporally for the fallen angel. Faustus, in his refusal to credit or contemplate Mephistopheles's narrative, insults his interlocutor: "Learn thou of Faustus manly fortitude, / And scorn those joys thou never shalt possess" (4.87-88). This is a significant moment of misreading, or of refusing once again to contextualize what he gathers - the joys that Mephistopheles "never shalt possess," we have already learned, are the same ones he did once, before human history, own. In failing to believe Mephistopheles's history, Faustus is asserting his own singularity; as the Chorus explains, Faustus is so enamoured with his seeming abilities in conjuration that he turns to necromancy, "[w]hich he prefers before his chiefest bliss" (Prologue, 27).

Mephistopheles mocks Faustus' limited understanding of temporal dilation. He is not troubled by his seemingly enforced stay at Faustus' side, if only because his condition of living without God renders his servitude a mere diversion, a duty to gain another soul for Satan that does not alter his own temporal realities. As he tells Faustus, he seeks to fill his own timeline with as many diversions as possible; he and Satan wish for others to be condemned to hell, because "Solamen miseris socios habuisse doloris [It is a comfort to the miserable to have had companions in sorrow]" (5.41). Similarly, Faustus' failure is not only of scope but of scale-in his allotted twenty-four years of demonic mastery, Faustus's tenure is depressingly without many accolades. Given a precise temporal span for gaining knowledge, Faustus learns little. He fails to comprehend or put to use the knowledge that Mephistopheles offers regarding the metaphysical and teleological constraints of preternatural time. His blind-spot rests upon one of the play's favorite terms - ends. Faustus repeatedly seeks the ends, the results, of his cosmological, teleological, and eschatological inquiries to his demonic familiar. This paradox is expressed most fully when the scholar readily signs away his soul: "Now will I make an end immediately" (5.72). Faustus aims to expedite his acquisition of knowledge, but he is locked into a temporal frame of ends - working toward his own pleasurable ends, the ends of the play's performance time, and the ends of human temporality itself. 
Despite his fixation on the ends of knowledge, power, and prestige, Faustus' interactions with Mephistopheles are initially characterized by dilatoriness on the part of the demon. In his first Latin invocation, Faustus demands — at this moment alone onstage — "Why do you delay?" (3.20). When Mephistopheles finally arrives, Faustus finds his true form too ugly for sociability, and directs the demon to reappear dressed as a friar. Once again Faustus is frustrated by the raised demon's sense of speed, asking “Quin redis, Mephistopheles, fratris imagine! [Why don't you return, Mephistopheles, in the guise of a friar!] (3.35). Mephistopheles is constantly moving offstage to return with books or spectacles, but at first he appears reluctant to heed Faustus' call for promptness. Faustus deludes himself into believing that his new demonic familiar is "pliant" and "[f]ull of obedience and humility" $(3.30 ; 31)$. But this readiness is only a mirage, one that is characterized by disinclination to perform Faustus' behests squarely, on or in Faustus' time. Each return brings gifts, but they distract Faustus by deferring contemplation of the one end that Mephistopheles refuses to disclose - the ends of Christ's sacrifice and the salvation of the repentant.

But Mephistopheles' manipulations of Faustus by furnishing pastimes are leavened with the demon's own temporal and spatial determinations. Having pilfered one of Faustus' books, the clowns Robin and Rafe deliver a string of nonsense in Latin and Greek that nonetheless calls forth Mephistopheles. ${ }^{38}$ With chagrin for this unwelcomed invocation, Mephistopheles curses the clowns and admits that he is not an entirely free agent:

Monarch of hell, under whose black survey

Great potentates do kneel with awful fear, Upon whose altars thousand souls do lie, How am I vexèd with these villains' charms!

From Constantinople am I hither come

Only for pleasure of these damnèd slaves (9.36-40).

Flying rapidly from one locale to another, Mephistopheles is under the sway of the demands of even Robin and Rafe, however untimely such requests might be. The demon's petty revenge degrades the clowns even further into beasts, but this punishment is met with levity.

Mephistopheles, it seems, is equally subject to the magical language and times as other early

\footnotetext{
38 These scenes may have been written by another author, perhaps Thomas Nashe. But for my purposes, the authorship is less of interest than what this temporal disconnect between the clowns and Mephistopheles says about the portions of the play that feature Faustus. See Paul H. Kocher, "Nashe's Authorship of the Prose Scenes in Faustus," Modern Language Quarterly 3 (1942): 17-40 and H. W. Crundell, "Nashe and Doctor Faustus," Notes \& Queries 207 (1962): 327.
} 
modern dramatic demons, and he is angry at his apparent constriction within a human realm of change and demands. Although in Doctor Faustus the demon arrives "per accidens" (3.47) for the great scholar, in other moments Mephistopheles is forced to adjust to the temporal and spatial mold of those who obtain the same inscrutable magical texts demonologists decried.

The human and demonic timeframes in the play meet with the most tension when the question of materiality intervenes in performance and Faustus' quest for unbounded knowledge.

For instance, Charles V requests to view the bodies of Alexander and his paramour in a fantastic scene that explicitly conjoins spectacle with the question of grand scales of temporality. Faustus admits, however, that as humans their bodies were subject to the vagaries of decay: "it is not in my ability to present before your eyes the true substantial bodies of those two deceased princes, which long since are consumed to dust" (10.45-47). Demons, though, are not subject to the same corporeal and temporal restrictions, and thus he offers "such spirits as can lively resemble" (10.50) the requested figures. The illusion is so effective that Charles echoes Faustus' language but does so in order to affirm that "these are no spirits, but the true substantial bodies of those two deceased princes" (10.69-70). The spectacle, empty as it is, occasions Faustus' acknowledgement that his own time is running short:

Now, Mephistopheles, the restless course That time doth run with calm and silent foot, Short'ning my days and thread of vital life, Calls for the payment of my latest years. Therefore, sweet Mephistopheles, let us make haste To Wittenberg. (10.97-102).

In this melancholy vein, Faustus has read carefully the length of his contract, and he knows that his time as human subject is nearing its end. The performance of demonic figures masking as humans reminds Faustus that, despite his magical prowess, he too is materially subject to the same decay as the figures he has only, as in a shadow, conjured. As the Horse-Courser's silly requests in the following scene occasion, Faustus is deeply aware that his "fatal time doth draw to final end" (11.30). Faustus continually defers confronting that final end directly - this end, like the false representations of Alexander and his paramour, is not a direct, true reality. Instead, Faustus will soon share the ageless, boundless temporal frame of his beloved Mephistopheles, without gaining those fruits of knowledge he was promised. Always believing that there is more earthly time, Faustus remains rooted to the pleasures the demon proffers; as Faustus consoles 
himself, "Tush! Christ did call the thief upon the cross; / Then rest thee, Faustus, quiet in conceit" (11.33-34).

Such are Faustus's desires for deferral, to find solace "quiet in conceit," that in this same scene, the magus is exhausted and ready to trudge back to his study, but when Wagner arrives bringing an invitation from the Duke and Duchess of Vanholt, Faustus readily accepts. At the Vanholt court, Faustus showcases his magical ability and his knowledge of the seasons, though as in his conjuration, Faustus can only intuit earthly temporal rhythms rather than grasping the full extent of what Mephistopheles's experiences of "for ever damned" imply. Bringing the pregnant Duchess some grapes, Faustus details for his audience his learning in cosmological temporality: "the year is divided into two circles over the whole world, that when it is here winter with us, in the contrary circle it is summer with them, as in India, Saba, and farther countries in the East" (12.21-24). Ironically, Faustus is incorrect here, given that east and west share seasonal patterns. Nonetheless, if Faustus impresses the Duke and Duchess with his mastery over seasons and time below the heavens, his construction of time beyond a cyclical, earth-bound model is woefully lacking.

Although offered the benefactions of "celestial rest" (13.38) by the Old Man, Faustus is once again presented with new sights that distract from understanding a providential or preternatural frame of time. The end of the play is so painful, in part, because Faustus finally understands the implications of what aligning human and preternatural time means. His desire to prolong time itself in his final speech serves as an agonizing reminder that no one-human or demon — can hope that "time may cease and midnight never come" (14.66). Unlike the typical communal gathering described in ars moriendi texts, the final moment for Faustus is a private affair, conducted intimately with only the Old Man in an aborted ars moriendi scene. Wagner is the first to critique Faustus's preparation for death; even as his student observes "I think my master means to die shortly" (13.1), he is also baffled by the magus's behaviour: "And yet methinks, if that death were near, / He would not banquet and carouse and swill / Amongst the students, as even now he doth" (13.3-5). But as the bells begin to toll, Faustus leaves off his banqueting and the Old Man arrives to minister to the fallen man. Marlowe presents the first part of the moriens's script faithfully, as Faustus initially despairs over the weight of his sins: "Hell calls for right, and with a roaring voice / Says, 'Faustus, come! Thine hour is come'” (13.49-50). But ars moriendi texts also specified that the moriens should have faithful companions who 
encourage the dying individual to turn to notions of redemption and repentance. The Old Man, fulfilling this role, begs Faustus to "call for mercy and avoid despair" (12.56). But Faustus, as learned as he is, has not read his ars moriendi texts to their fullest explication, and instead of relying on the communal and performative narratives in the genre asks to be left alone, telling the Old Man to "[1] eave me a while to ponder on my sins" (13.59). As we have seen, the "a while" is increasingly constricted for both Faustus and his demons. What Faustus fails to understand is that time is not cyclic or only explicable in cosmological frames, and his attempts to dictate or control the flow of time fall woefully short in the course of his own brief narrative. Finally confronted by the full implications of his contract, Faustus's dying is artless, and he wishes for dissolution of the self or a reconceptualization of "damned for ever" that might include an end-point. With one hour left to live, Faustus cries out:
Ah, Faustus, Now hast thou but one bare hour to live, And then thou must be damned perpetually. Stand still, you ever-moving spheres of heaven, That time may cease and midnight never come!
Fair nature's eye, rise, rise again, and make Perpetual day, or let this hour be but A year, a month, a week, a natural day, That Faustus may repent and save his soul! O lente, lente currite noctis equi! (14.62-71).

As rhetorically poignant as this speech is, Faustus's understanding is still earthly; he begs for a prolongation of time that is grounded in the movements of the heavens and earth, without considering that time works different for demonic beings. Faustus, finally, is made to occupy demonic temporality rather than an earthly one that can be charted with scientific precision. Even if given more time, Faustus would still be left with the harrowing fact that " $[\mathrm{t}]$ he stars move still, time runs, the clock will strike, / The devil will come, and Faustus must be damned" (14.72-73).

As I have suggested, Marlowe's play explores the failure of characters to understand that magical or demonic agents operate outside of their own temporal frames. Magicians might wait until midnight or when astral figures align in particular ways to perform their invocations, but such precision is laughable when the very figures invoked operate upon different temporal experiences. Afforded seemingly illimitable power and spatial scope, however, demons too are bound by certain times or materials onstage. But this may, after all, be a ruse. Marlowe in particular mocks the demonological assumption that such figures can be brought in line with 
material, human wishes and timescales. The stage has always negotiated a thin line between orthodoxy and blasphemy. One way to tread this invisible line was to position Satan as the imaginary counterpoint to redeemed humans and to maintain the moralistic purpose of viewing, and rejecting, a fallen human magus, as the Epilogue to Doctor Faustus enjoins its audiences to do: we are to "regard" but not participate in Faustus's necromantic study, "[w]hose deepness doth entice such forward wits / To practice more than heavenly power permits" (Epilogue, 4, 78). Fittingly, the printed text follows the Epilogue with the adage, "Terminat hora diem; terminat author opus," which translates to "the hour ends the day, the author ends his work." For a play so focused on ends, demonic temporality tends to slip through the epistemic and ontological understanding of demons that Doctor Faustus's human characters wield. The period's demonology and ars moriendi texts also attempted to understand how to square the "hour" of human lifetime with the preternatural times of otherworldly beings alongside notions of everlasting existence in either heaven or hell. Falling through the cracks, however, are the disparate ways that Satan and his cohort of demons work against this perspective, both aligning with but then moving both before and after these temporal explications. Demonic temporality, in Doctor Faustus, challenges a reading of narrative itself, when we cannot fully account for the narrative of the moriens, or Faustus, if those like Mephistopheles are the ones teaching him about possible afterlives.

As Stuart Clark notes, the flourishing of demonology and witchcraft beliefs was attributed in part to an obsession with "the temporal dynamics of demonism." This field of study was thus "a reflection on history," and, importantly, an attempt to understand the effects that such a history could have on the susceptibility of human bodies to the appearance and influence of Satan. ${ }^{39}$ In contention in the demonological texts of the period are various forms of "end times" that the Devil and his agents operate within or beyond. But as scholars from the period were forced to admit, albeit obliquely, demonic time, even when placed within these frameworks, was impossible to explicate fully. On the early modern stage, such frissons were performed in the present, often during the day, and thus pointed to further performative problems in locating the precise functioning of preternatural time when compared to that of the human actors onstage. Doctor Faustus highlights the uncanny ways that the Devil can play with time and manipulate how others perceive his experiences within multiple temporal frameworks. Just

\footnotetext{
${ }^{39}$ Clark, Thinking with Demons, 316.
} 
as at the moriens's bedside, demons in this play work to frame their own temporalities with the human subject's sense of mortality, of finitude. But Doctor Faustus also pushes back against Satan's histories and tendencies, showing how demons too can, despite Scot's scepticism, be so sedimented in temporal ways of thinking that they are subject to the "times" that demons only flit through before moving on to the next moriens, the next conjuror who adopts the "shortest cut for conjuring" (3.53) in expediting his timeline to damnation.

\section{Bibliography}

Almond, Philip C. The Devil, A New Biography. Ithaca, NY: Cornell University Press, 2014. Anonymous. The Merry Devil of Edmonton. Edited by Nicola Bennett. London: Routledge, 2000.

Barrett, J. K. Untold Futures: Time and Literary Culture in Renaissance England. Ithaca, NY: Cornell University Press, 2016.

Beaty, Nancy Lee. The Craft of Dying: A Study in the Literary Tradition of the ars moriendi in England. New Haven: Yale University Press, 1970.

Becon, Thomas. The sicke mans salue. London, 1568.

Boesky, Amy. "Giving Time to Women: The Eternising Project in Early Modern England.” In This Double Voice: Gendered Writing in Early Modern England, edited by Danielle Clarke and Elizabeth Clarke, 123-41. Basingstoke: Macmillan, 2000.

Browne, Sir Thomas. Sir Thomas Browne: The Major Works. Edited by C. A. Patrides. Harmondsworth: Penguin, 1977.

Brownlee, Victoria. Biblical Readings and Literary Writings in Early Modern England, 15581625. Oxford: Oxford University Press, 2018.

Bullinger, Heinrich. A hundred sermons vpo[n] the Apocalips of Iesu Christe reueiled in dede by thangell of the Lorde. London, 1561.

Bushnell, Rebecca. Tragic Time in Drama, Film, and Videogames: The Future in the Instant. London: Palgrave Macmillan, 2016.

Clark, Stuart. Thinking with Demons: The Idea of Witchcraft in Early Modern Europe. Oxford: Oxford University Press, 1999. 
Cox, John. The Devil and the Sacred in English Drama, 1350-1642. Cambridge: Cambridge University Press, 2000.

Crundell, H. W. "Nashe and Doctor Faustus." Notes \& Queries 207 (1962): 327.

Defoe, Daniel. The Political History of the Devil. London, 1726.

Erasmus, Desiderius. Preparation to deathe. London, 1538.

Floyd-Wilson, Mary. Occult Knowledge, Science, and Gender on the Shakespearean Stage. Cambridge: Cambridge University Press, 2013.

The Geneva Bible, a Facsimile of the 1560 Edition. Introduction by Lloyd E. Berry. Geneva, 1560; Madison: University of Winsconsin Press, 1969.

Glennie, Paul and Nigel Thrift. Shaping the Day: A History of Timekeeping in England and Wales, 1300-1800. Oxford: Oxford University Press, 2009.

Harris, Jonathan Gil. Untimely Matter in the Time of Shakespeare. Philadelphia: University of Pennsylvania Press, 2009.

Homes, Nathanael. Daemonologie, and Theologie The first, the Malady, Demonstrating the Diabolicall Arts, and Devillish Hearts of Men. The second, the Remedy: Demonstrating, God a Rich Supply of all Good. London, 1650.

James VI \& I. Daemonologie in Forme of a Dialogue. Edinburgh, 1587.

Johnstone, Nathanael. The Devil and Demonism in Early Modern England. Cambridge: Cambridge University Press, 2006.

Kastan, David Scott. Shakespeare and the Shapes of Time. London: Palgrave Macmillan, 1982.

Kocher, Paul H. "Nashe's Authorship of the Prose Scenes in Faustus." Modern Language Quarterly 3 (1942): 17-40.

Lande, David. Revolution in Time: Clocks and the Making of the Modern World. Cambridge, MA: Harvard University Press, 2000.

Lewis, Sarah. "Shakespeare, Time, Theory." Literature Compass 11, no. 4 (2014): 246-57.

Marlowe, Christopher. Christopher Marlowe: The Complete Plays. Edited by Frank Romany and Robert Lindsey. London: Penguin, 2003.

Marlowe, Christopher. Doctor Faustus: A- and B-Texts (1604, 1616). Edited by David Bevington and Eric Rasmussen. Manchester: Manchester University Press, 1993.

Millar, Charlotte-Rose. Witchcraft, the Devil, and Emotions in Early Modern England. New York: Routledge, 2017. 
Oldridge, Darren. The Devil in Early Modern England. Stroud: Sutton, 2002.

Pickering, Thomas. Preface to William Perkins, A Discourse of the Damned Art of Witchcraft. London, 1610.

Poole, Kristen. Supernatural Environments in Shakespeare's England: Spaces of Demonism, Divinity, and Drama. Cambridge: Cambridge University Press, 2011.

Russell, Jeffrey Burton. The Devil: Perceptions of Evil from Antiquity to Primitive Christianity. Ithaca, NY: Cornell University Press, 1977.

Schäfer, Daniel. Old Age and Disease in Early Modern Medicine. Translated by Patrick Baker. New York: Pickering \& Chatto, 2016.

Scot, Reginald. The Discovery of Witchcraft. London, 1584.

Shakespeare, William. Hamlet, ed. Ann Thompson and Neil Taylor. London: Bloomsbury, 2014.

Shakespeare, William. Othello. Edited by E. A. J. Honigmann. London: Bloomsbury, 2014.

Shohet, Lauren, ed. Temporality, Genre and Experience in the Age of Shakespeare: Forms of Time. London: Bloomsbury, 2018.

Sofer, Andrew. "How to Do Things with Demons: Conjuring Performatives in Doctor Faustus." Theatre Journal 61, no. 1 (2009): 1-22.

Streete, Adrian. Apocalypse and Anti-Catholicism in Seventeenth-Century Drama. Cambridge: Cambridge University Press, 2017.

Stubbes, Philip. A Christal Glas for Christian Women. London, 1591.

Sutton, Christopher. Disce mori. Learne to die. A religious discourse, moouing euery Christian man to enter into a serious remerbrance of his ende. London, 1600.

Van Dijkhuizen, Jan Frans. Devil Theatre: Demonic Possession and Exorcism in English Renaissance Drama, 1558-1642. Cambridge: Boydell \& Brewer, 2007.

Vinter, Maggie. Last Acts: The Art of Dying on the Early Modern Stage. New York: Fordham University Press, 2019.

Wagner, Matthew. Shakespeare, Theatre, and Time. London: Routledge, 2012.

Weyer, Johann. Witches, Devils, and Doctors in the Renaissance: Johann Weyer, 'De praestigiis daemonum,' edited by George Mora and translated by John Shean. Binghamton NY: Medieval and Renaissance Texts and Studies, 1991.

Wood, David Houston. Time, Narrative and Emotion in Early Modern England. Farnham: Ashgate, 2009. 
Demonic Temporality in Marlowe's Doctor Faustus

Wunderli, Richard and Gerald Broce. "The Final Moment before Death in Early Modern England." The Sixteenth Century Journal 20, no. 2 (Summer 1989): 259-75. 